\title{
Perubahan Mata Pencaharian dan Proses Adaptasi Warga Terkena Dampak Pembangunan Waduk Jatigede
}

\author{
Valentina Wijayanto ${ }^{1}$, Opan S. Suwartapradja ${ }^{2}$, Rina Hermawati ${ }^{3}$ \\ ${ }^{1}$ Program Studi Sarjana Antropologi, FISIP, Universitas Padjadjaran \\ valenewss@gmail.com \\ ${ }^{2,3}$ Departemen Antropologi, FISIP, Universitas Padjadjaran
}

\begin{abstract}
The construction of Jatigede dam has brought social, economic, and cultural impact towards the daily living of the surrounding community. One of the socio-economic impacts is the loss of livelihood. As the consequence the community members need to change their form of livelihood and adjust it to the characteristics of the new environment where they live. This study describes the livelihood change and adaptation of community members impacted by the construction of Jatigede dam. It aims at describing the change at the level of infrastructure and structure of the culture in regards with livelihood change of the community using theory of cultural materialism by Marvin Harris as the perspective. This study was conducted using qualitative methods. The result of the study suggests that the changing geographical landscape has brought change to livelihood change from agricultural farming to non-agricultural. In line with this change, community members use their social relations, intra or intergroup, in order to utilize and to adjust to the available resources in the new environment as well as to adjust to it.
\end{abstract}

Keywords: adaptation, livelihood, community, development

\begin{abstract}
Abstrak
Pembangunan Waduk Jatigede telah menimbulkan berbagai dampak sosial, ekonomi dan budaya bagi warga yang tinggal di are yang dijadikan waduk. Salah satu dampak sosial ekonomi yang dirasakan oleh warga masyarakat yang terdampak (WMT) adalah kehilangan mata pencaharian. Akibatnya, mereka harus mencari bentuk mata pencaharian baru yang sesuai dengan karakteristik tempat tinggalnya yang baru. Penelitian ini mendeskripsikan perubahan bentuk mata pencaharian dan proses adaptasi yang dilakukan oleh warga masyarakat yang terdampak penggenangan Waduk Jatigede di Dusun Ancol, Desa Karang Pakuan. Penelitian ini mendeskripsikan perubahan pada level infrastruktur dan struktur kebudayaan yang mempengaruhi perubahan mata pencaharian warga terdampak genangan dengan menggunakan perspektif teori Marvin Harris mengenai materialisme kebudayaan. Metode penelitian yang digunakan adalah kualititatif. Hasil penelitian menunjukkan bahwa perubahan bentang alam telah menyebabkan perubahan kondisi sosial ekonomi, termasuk di dalamnya perubahan mata pencaharian dari pertanian menjadi non pertanian. Warga berupaya menyesuaikan diri dengan perubahan itu dengan memanfaatkan relasi-relasi sosial baik relasi intergrup maupun intragrup. Hal itu mereka lakukan agar dapat memanfaatkan sumber daya baru yang ada dan menyesuaikan diri secara sosial di lingkungan baru mereka
\end{abstract}

Kata kunci : adaptasi, mata pencaharian, masyarakat, pembangunan. 


\section{Pendahuluan}

Pada dasarnya pembangunan memiliki tujuan untuk kemajuan masyarakat. Rogers dalam Zulkarimen (2007) mengungkapkan bahwa pembangunan adalah suatu proses perubahan sosial dengan tingkat partisipatori yang luas dalam suatu masyarakat yang dimaksudkan untuk kemajuan sosial dan material (termasuk bertambah besarnya kebebasan, keadilan dan kualitas lainnya yang dihargai) untuk mayoritas rakyat melalui kontrol yang lebih besar yang mereka peroleh terhadap lingkungan mereka. Namun, pembangunan tidak dapat dilepaskan dari berbagai dampak yang ditimbulkan karena perubahan fisik dan sosial. Salah satu pembangunan yang mengakibatkan perubahan fisik dan sosial yang sangat besar adalah pembangunan Waduk Jatigede yang terletak di Kabupaten Sumedang, Provinsi Jawa Barat.

Waduk Jatigede dibangun di areal lahan sawah dan desa yang berpenduduk ramai. Proses ganti rugi tanah warga dilaksanakan selama 22 tahun (1982-2004) dan puncaknya pada 31 Agustus 2015, saat pembangunan intensif dan penggenangan mulai dilakukan. Pembangunan Waduk Jatigede bertujuan untuk mengendalikan banjir di wilayah Indramayu, mengatur pengairan sawah di daerah Indramayu, Cirebon, dan daerah di sekitarnya, sumber pembangkit listrik, tempat pariwisata dan pengadaan air baku untuk industri dan atau domestik. Secara fisik, pembangunan Waduk Jatigede telah menenggelamkan seluas 6.738 hektar tanah yang meliputi: sawah, hutan, permukiman rakyat, ladang, kebun, jalan desa, sekolah, tempat peribadatan dan lainlain di dalam 35 desa di 5 kecamatan yaitu: Wado, Darmaraja, Situraja, Cadas-ngampar dan Tomo. Sedangkan jumlah penduduk yang harus dipindahkan dari lokasi genangan berdasarkan hasil sensus yang dilakukan oleh PPSDAL tahun 2000, berjumlah sekitar 6.642 KK atau sekitar 19.542 jiwa.
Pembangunan Waduk Jatigede merupakan pembangunan di bidang infrastruktur. Pembangunan ini turut mempengaruhi berubahnya sumber daya, dari semula sumber daya lahan (terrestrial) menjadi sumber daya air (aquatiq). Seiring dengan ini, perubahan kehidupan dan penghidupan warga di lokasi yang telah tergenang waduk pun berubah drastis. Dampak dari penggenangan ini adalah 1) perubahan tempat tinggal masyarakat dan 2) hilangnya mata pencahariannya warga di beberapa desa yang mulanya mengandalkan pertanian lahan sawah di lokasi genangan. Tidak hanya petani pemilik dan penggarap yang kehilangan mata pencaharian, tetapi juga buruh tani.

Perubahan lokasi tempat tinggal mengharuskan warga melakukan aneka bentuk adaptasi dengan lingkungan baru termasuk pula adaptasi pada perubahan mata pencaharian. Ekosistem lahan yang telah berubah menjadi perariran tidak langsung membuat mereka dapat langsung untuk memanfaatkan sumber daya yang baru itu. Minimnya minat pada mata pencaharian berbasis air di kalangan warga terdampak adalah akibat dari minimnya pengetahuan mengenai potensi, kurangnya keahlian dan kurangnya modal untuk mengolah sumber daya baru tersebut

Hasil survai sebuah penelitian oleh para dosen di Universitas Padjadjaran 2015 menemukan bahwa sebagian besar warga yang terdampak pembangunan waduk bekerja di lahan sawah. Sebanyak 69,3\% penduduk itu pun berencana untuk bekerja lagi di bidang pertanian. Hal ini dapat dipahami mengingat pertanian adalah mata pencaharian yang merek ageluti bertahuntahun dan mereka tidak mempunyai keahlian dan keterampilan lainnya di luar pertanian (Suwartapradja, 2015). Namun, keinginan warga untuk tetap bekerja di bidang pertanian tidak didukung oleh adanya peluang kerja tersebut di tempat baru. 
Pemilik lahan di tempat tinggal yang baru sudah memiliki buruh tani atau petani penggarap. Bekerja pada petani kaya atau mengikuti patron yang telah terjalin selama berada di daerah tapak proyek juga tidak memungkinkan karena luas kepemilikan lahan pertaniannya semakin berkurang. Dengan demikian, fenomena "pemutusan hubungan kerja atau PHK” menjadi hal yang sangat umum (Suwartapradja, 2017a).

Penelitian ini berupaya mendeskripsikan perubahan penghidupan masyarakat terdampak pembangunan waduk Jatigede dan bagaimana mereka melakukan adaptasi dengan mata pencaharian mereka yang baru tersebut. Pada kasus relokasi, lahan pertanian sebagai sumber daya alam yang menjadi tumpuan hidup warga boleh jadi hilang tetapi tak dapat diabaikan. Namun setidaknya, warga dapat meminimalisir dan menyelesaikan dengan cara membuat rencana awal yang matang dan tindakan yang tepat (Lagler dalam Fahim, 1981).

\section{Kajian Pustaka}

Effendi (2002) menyebutkan bahwa pembangunan adalah suatu upaya meningkatkan segenap sumber daya yang dilakukan secara berencana dan berkelanjutan dengan prinsip daya guna yang merata dan berkeadilan. Pembangunan (development) juga merujuk pada proses perubahan yang men-cakup seluruh sistem sosial, seperti politik, ekonomi, infrastruktur, pertahanan, pendidikan dan teknologi, kelembagaan, dan budaya (Alexander dalam Harahap, 2015).

Pembangunan Waduk Jatigede merupakan pembangunan yang menyebabkan perubahan pada segi lingkungan fisik yang berakibat pada perubahan lingkungan sosial dan ekonomi. Hal ini disebabkan oleh adanya perpindahan tempat tinggal masyarakat terdampak ke tempat tinggal baru mereka. Perubahan ini menuntut mereka untuk melakukan adaptasi atau penyesuaianpenyesuaian diri terhadap kondisi lingkungan yang ada ataupun yang telah berubah.

Konsep adaptasi merujuk pada kemampuan individu untuk mengatasi keadaan lingkungan dan menggunakan sumbersumber alam lebih banyak untuk mempertahankan hidupnya dalam relung yang diduduki (Irwan, 2014). Adaptasi juga merujuk pada suatu penyesuaian pribadi terhadap lingkungan. Penyesuaian berarti mengubah diri pribadi sesuai dengan keadaan lingkungan, juga dapat berarti mengubah lingkungan sesuai dengan keadaan keinginan pribadi (Gerungan, 2009).

Adaptasi merupakan salah satu bagian dari proses evolusi kebudayaan, yakni proses yang mencakup rangkaian usaha-usaha manusia untuk menyesuaikan diri atau memberi respon terhadap lingkungan fisik maupun sosial yang terjadi secara temporal (Mulyadi,2007 dalam Satria, 2012). Batasan konsep adaptasi menurut Soekanto (2000 adalah : 1) Proses mengatasi halanganhalangan dari lingkungan; 2)Proses perubahan-perubahan menyesuaikan dengan situasi yang berubah; 3) mengubah agar sesuai dengan kondisi yang diciptakan; 4) memanfaatkan sumber-sumber yang terbatas untuk kepentingan lingkungan dan sistem; 5) penyesuaian budaya dan aspek lainnya sebagai hasil seleksi alamiah. Salah satu upaya adaptasi yang dilakukan manusia agar dapat bertahan hidup di antaranya yakni berupa adaptasi sosial dan kebudayaan. Adaptasi kebudayaan dapat didefinisikan sebagai suatu strategi penanggu-langan yang diupayakan manusia dalam kehidupannya untuk merespon perubahan lingkungan maupun perubahan sosial (Iskandar dalam Harahap, 2015). Adaptasi mata pencaharian dilakukan agar manusia tetap dapat menyesuaikan diri dengan lingkungan baru mereka sekaligus bertahan hidup. Pada umumnya, manusia yang berada di lingkungan baru akan berupaya menyesuaikan diri dengan sumber daya yang tersedia di lingkungan barunya.

Pada konteks penggenangan waduk Jatigede, warga yang terkena dampak pembangunan 
waduk dapat beradaptasi dalam hal mata pencaharian dengan menjadi nelayan, penangkap ikan, tukang perahu, dan sejenisnya untuk dapat bertahan hidup dan ini merupakan salah satu bentuk adaptasi mereka pada lingkungan baru dan sumber daya lam baru (Fahim, 1981).

Sumber daya merupakan sebuah infrastuktur. Prinsip teoretis mendasar dari materialisme kebudayaan adalah prinsip determinisme infrastruktur (Harris, 1979). Lebih lanjut Harris mengatakan bahwa mode perilaku etik dari produksi dan reproduksi secara probabilitas menentukan perilaku ekonomi etik domestik dan ekonomi politik, yang kemudian secara probabilitas menentukan suprastruktur perilaku emik dan suprastruktur mental emik. Dampak pembangunan terhadap adaptasi dapat dilihat dalam konsep materialisme budaya Marvin Harris (1979). Konsep awalnya yakni determinisme lingkungan yang menyatakan bahwa infrastruktur kebudayaan dapat secara probabilitas mengubah keadaan struktur kebudayaan.

Adapun yang termasuk infrastruktur adalah mode of production dan mode of reproduction. Mode of production atau moda produksi adalah teknologi dan praktikpraktik yang digunakan untuk memperluas atau membatasi produksi subsistensi dasar, khususnya produksi makanan dan bentukbentuk energi lainnya. Hambatan dan kesempatan biasanya timbul karena interaksi teknologi spesifik tertentu dengan habitat tertentu (Saifuddin, 2005). Moda produksi meliputi teknologi sub-sistensi, hubungan teknolingkungan, ekosistem, dan pola-pola kerja. Variabel dalam moda reproduksi adalah demografi, pola-pola perkawinan, fertilitas, natalitas, mortalitas, Pengasuhan anak, Pengendalian medis atas pola-pola demografi, kontrasepsi, aborsi, dan infantisida. Sedangkan yang dimaksud mode reproduksi (mode of reproduction) adalah teknologi dan praktik-praktik yang diterapkan untuk memperluas, membatasi, dan mempertahankan ukuran populasi. Di dalam konsep determinisme lingkungan disebutkan bahwa perubahan infrastruktur secara probabilitas dapat merubah struktur kebudayaan. Adapun variabel dalam tingkat struktur adalah political economy dan domestic economy ekonomi domestik. Konsep ekonomi domestic merujuk pada adalah pengor-ganisasian reproduksi dan produksi dasar, tukar-menukar, dan konsumsi dalam rumah tangga, apartemen, atau tatanan domestik lainnya. Konsep ini meliputi struktur keluarga, pembagian kerja domestic, sosialisasi domestic, enkulturasi, pendidikan, peranan usia dan jenis kelamin, displin domestik, hierarki, sanksi.

Konsep ekonomi politik merujuk pada pengorganisasian reproduksi, produksi, pertukaran dan konsumsi dalam dan di antara bandband, desa-desa, chiefdoms, negara, dan kerajaan. Konsep ini meliputi organisasi politik, faksi, klub, asosiasi, korporasi, Pemagian kerja, pajak, dan pungutan, sosialisasi politik, enkulturasi, pendidikan, kelas, kasta, hierarki kota-desa, displin, kontrol polisi/tantara, perang.

Infrastruktur dan struktur pada akhirnya dapat mempengaruhi suprastruktur perilaku. Konsep suprastruktur perilaku digunakan untuk meng-gambarkan kondisi yang dimiliki kebudayaan pada level abstrak, yaitu berupa kepercayaan, ideologi, dan seni. Variabel yang termasuk dalam suprastruktur perilaku adalah seni musik, tari-tarian, sastra, periklanan, ritual, olahraga, permainan, hobi, Ilmu pengetahuan. Pada penelitian ini kajian dibatasi hanya pada level infrastruktur dan struktur kebudayaan saja. Pada infrastruktur, variabel yang digunakan yakni ekosistem, pola kerja, teknologi, demografi. Sedangkan pada level struktur, variabel yang digunakan ialah pembagian kerja domestik, relasi intergrup dan intragrup masyarakat terdampak.

Definisi dari 'masyarakat terdampak' yang dimaksud dalam penelitianini adalah masyarakat yang semula tinggal di daerah rencana genangan (tapak proyek) yang assetnya hilang dan harus pindah, dan masyarakat yang tinggal diluar rencana genangan (tapak proyek) yang kehilangan 
asset dan pencaharian di daerah tersebut. (Suwartapradja, 2015).

\section{Metode}

Penelitian ini menggunakan metode kualitatif. Metode kualitatif adalah suatu pendekatan yang menggunakan pendekatan pengamatan mendalam karena proses pengumpulkan data dilakukan dengan cara bertatap muka langsung dan berinteraksi dengan subyek penelitian (McMillan dan Schumacher, 2003). Metode ini dipilih didasarkan pemahaman bahwa perubahan sumber daya alam memerlukan kajian yang lebih mendalam terkait dengan proses adaptasi dalam mempertahankan kelangsungan hidup

\section{Hasil dan Pembahasan}

\section{Materialisme Budaya Marvin Harris Pada Tingkat Infrastruktur}

Marvin Harris dalam teorinya mengenai materialisme budaya menyebutkan bahwa infrastruktur kebudayaan secara probabilitas dapat mempengaruhi tingkat kebudayaan yang lain. Dilihat dari fungsinya, infrastruktur kebudayaan adalah teknologi dan cara yang dilakukan oleh suatu masyarakat dalam rangka mengolah (memperluas atau membatasi) hal-hal dasar terkait makanan (energi) dan reproduksi agar tidak menghambat kehidupan masyarakat tersebut yang terbagi dalam moda produksi dan moda reproduksi. Infrastruktur yang dibahas dalam penelitian ini merujuk pada ekosistem, teknologi, pola kerja, dan demografi.

\section{Ekosistem (Perubahan Sumber Daya)}

Pembangunan Jatigede telah menyebabkan perubahan sumber daya alam yang ada, dari sumber daya lahan menjadi sumber daya air. Perubahan sumber daya ini telah mengubah tatanan ekosistem dari wilayah yang menjadi tapak proyek tersebut. Di lokasi sebelum penggenangan masyarakat terdampak yaitu Desa Cibogor, Desa Jatibungur, dan Desa Sukaratu sebagian besar wilayahnya merupakan daerah pertanian. Di Desa Sukaratu, dari total 130, 11 hektar luas wilayah, 99, 58 hektar adalah lahan persawahan dan ladang. Sedangkan di Desa Cibogo, dari total luas wilayah 355, 57 hektar, lebih dari 70 \% wilayahnya merupakan lahan sawah dan perkebunan. Pasca penggenangan, masyarakat terdampak dari beberapa desa sebagian besar berpindah ke wilayah dusun terdekat, yaitu Dusun Ancol. Di dusun ini terdapat warga masyarakat terdampak dari 3 lokasi desa yang berbeda. Mereka menempati wilayah di dusun itu yang tidak tergenang air serta mulai mencari mata pencaharian baru di bidang perairan. Hal ini disebabkan sebagian besar luas wilayah Dusun Ancol juga merupakan perairan.

Dampak pada lingkungan fisik akibat pembangunan Waduk Jatigede adalah berkurangnya lahan sawah. Berdasarkan tataguna lahan area waduk ini sekitar 60\% merupakan bekas lahan sawah, 20\% lahan kering/ darat/ tegalan, $10 \%$ lahan permukiman dan sekitar 10\% lahan kehutanan. Area yang termasuk ke dalam wilayah tampung air atau luas area waduk Jatigede 4.887 ha pada elevasi 262,5 m dpl (Suwartapradja, 2008). Hal ini berarti sebagian besar sawah telah tergenang menjadi waduk. (Suwartapradja, 2008). Perubahan tatanan ekologi ini telah membuat warga berganti memanfaatkan perairan untuk dapat bertahan hidup.

\section{Teknologi}

Perubahan penggunaan alat atau media untuk bekerja, menjadi variabel yang penting untuk diperhatikan dalam mengamati perubahan penghidupan dan proses adaptasi. Masyarakat terdampak yang sebelumnya berprofesi sebagai petani, dan kini telah berganti bentuk mata pencaharian; mulai menggunakan alat/media bekerja yang berbeda. Sebelum penggenangan, alat pertanian atau perkebunan adalah jenis teknologi yang digunakan para warga; berupa cangkul, topi, semprotan pestisida, traktor, dan hal lain yang terkait pertanian. Setelah penggenangan, alat bekerja mereka 
berganti menjadi perahu, jaring, alat waring, dan sebagainya yang terkait dengan kegiatan perairan.

Teknologi alat tangkap kini mulai dikenal para warga. Dengan demikian, moda produksi di Dusun Ancol Jatigede telah mengalami perubahan seiring dengan perubahan ekosistem. Kehandalan teknologi ini sangat berpengaruh pada kemampuan jelajah operasional mereka (Imron, dalam Haryono 2003).

\section{Pola Kerja}

Pola kerja menyangkut waktu kerja, dan bagaimana sistem upah dan pembagian hasil keuntungan dari suatu hal yang dikerjakan. Sebelum penggenangan, sistem upah didasarkan pada bagi hasil pertanian. Sebelum penggenangan, pola kerja mereka adalah bekerja sebagai pemilik sawah dan buruh tani. Pada saat musim panen, pemilik lahan sawah akan memberikan upah setiap kali mereka bekerja membantu panen pemilik sawah. Selain itu, ikatan antara petani pemilik dan buruh tani lebih kompleks dengan adanya sistem patron klien yang membuat hubungan mereka erat dan terikat. Namun, setelah penggenangan, sistem upah atau bagi hasil (terutama pertanian) sudah tidak ada lagi. Sebab, di tempat tinggal baru yaitu di Dusun Ancol, jarang sekali yang memanfaatkan lahan darat sebagai cara untuk mendapatkan mata pencaharian. Saat ini, warga Dusun Ancol tidak lagi memanfaatkan pola patron-klien dalam pembagian hasil sebagaimana dalam konteks pertanian lahan darat. Masih minimnya penghasilan dari penghidupan baru membuat warga berupaya keras memaksimalkan tenaga kerja yang dapat dimanfaatkan dalam keluarga seperti anak dan istri untuk menghemat atau memangkas biaya produksi dari pekerjaan baru mereka.

Perubahan sumber daya membuat warga melakukan upaya-upaya strategis untuk memaksimalkan hasil yang bisa didapatkan. Oleh karena itu, perubahan gaya hidup juga terjadi dalam keluarga yang tujuannya untuk menyesuaikan dengan situasi. Anggota keluarga menyesuaikan peran kerja sesuai dengan pekerjaan yang saat ini.

\section{Demografi}

Wilayah waduk pada mulanya merupakan daerah pertanian dengan lahan aktif dan jumlah panen 2 kali setahun. Desa Sukaratu misalnya, memiliki lahan persawahan seluas 80,26 hektar, lahan ladang/tegalan seluas 19,52 hektar. Satu kali panen, warga mendapatkan hasil 3-5 kwintal padi dari lahan seluas 0,1 ha. Hasil ini dirasa cukup untuk memenuhi kebutuhan sehari-hari.

Dusun Ancol adalah salah satu wilayah yang turut tergenang. Namun, wilayah bagian barat dusun ini tidak turut tergenang. Wilayah barat dusun ini merupakan salah satu yang paling diminati sebagai wilayah tujuan pindah para warga terdampak genangan. Dusun ini berbatasan langsung dengan dusun-dusun yang kini telah tergenang dan bisa dikatakan sebagai wilayah terdekat.

Perpindahan penduduk dari wilayah yang tergenang ke tempat tinggal baru menyebabkan terjadinya perubahan komposisi penduduk di wilayah tempat tinggal baru. Berikut adalah perubahan komposisi penduduk Desa Karangpakuan sebelum dan setelah penggenangan :

Tabel 1. Komposisi Penduduk Berdasarkan Jenis Kelamin Sebelum dan Setelah Penggenangan

\begin{tabular}{|c|c|c|c|c|}
\hline \multirow[t]{2}{*}{ No } & \multirow{2}{*}{$\begin{array}{c}\text { Jenis } \\
\text { Kelamin }\end{array}$} & Sebelum & Setelah & \multirow{2}{*}{$\begin{array}{c}\text { Peningkatan } \\
(\%)\end{array}$} \\
\hline & & \multicolumn{2}{|c|}{ Penggenangan } & \\
\hline 1 & Lk & 1.814 & 2.320 & 27,9 \\
\hline 2 & $\operatorname{Pr}$ & 1.782 & 2.163 & 21,4 \\
\hline $\begin{array}{l}\text { Jun } \\
\text { kes }\end{array}$ & $\begin{array}{l}\text { jiwa } \\
\text { uhan }\end{array}$ & 3596 & 4483 & \\
\hline
\end{tabular}

Sumber : Olahan Data Badan Pusat Statistik

Kab. Sumedang

Tabel 1 menunjukkan peningkatan jumlah penduduk laki-laki sebesar 27,9 \% dan pertambahan jumlah penduduk perempuan sebanyak 21,4 \% dari sebelum penggenangan. Jumlah ini menggambarkan peningkatan kompetisi mendapatkan pekerjaan di tempat tinggal baru pasca penggenangan. Hal ini karena warga Desa yang menjadi 
tempat rekolasi harus bersaing dengan para pendatang yang memiliki keahlian sama, yaitu pertanian. Persaingan menguasai lahan pertanian dan pekerjaan di bidang pertanian pun terjadi. Persaingan ini lalu mendorong terbentuknya strategi warga agar tetap dapat mencari penghidupan.

\section{Materialisme Budaya Marvin Harris Pada Tingkat Struktur}

Struktur kebudayaan adalah pengorganisasian reproduksi dan produksi dasar, tukarmenukar, dan konsumsi dalam lingkup domestik maupun publik (hubungan masyarakat dengan lembaga sosial). Pada tingkat struktur terdapat politik ekonomi dan domestik ekonomi. Pada konsep ini, variabel yang dibahas adalah pembagian kerja domestik, dan hubungan intergrup dan intragrup yang memiliki tujuan tertentu.

\section{Pembagian Kerja Domestik}

Marvin Harris menyebutkan bahwa dalam tingkat struktur, perubahan infrastruktur secara probabilitas dapat mengubah tatanan struktur suatu kebudayaan. Salah satu konsep struktur yang dimaksud oleh Mavin Harris adalah pembagian kerja domestik. Dalam rangka untuk memenuhi kebutuhan seharihari, warga terdampak genangan harus memaksimalkan kinerjanya dan meminimalisir semua pengeluaran produksi agar hasil atau keuntungan dapat didapatkan dengan mak-simal.

Sebelum penggenangan, anggota keluarga masyarakat terdampak melakukan pembagian kerja untuk mendukung perekonomian terutama dalam bidang pertanian. Di dalam bertani, biasanya kepala keluarga (bapak) dibantu oleh ibu (istri) untuk melakukan aktivitas pertanian. Para istri bisa membantu dalam proses pra panen, ataupun pasca panen. Para istri akan membantu pula dalam proses nandur atau proses penanaman benih padi di lahan sawah mereka. Setelah itu, tugas memberi pupuk atau menyemprot pestisida menjadi tugas laki-laki atau suami. Pada saat panen, biasanya baik istri dan suami sama-sama bekerja untuk mengolah hasil panennya sampai siap jual. Setelah penggenangan, banyak kepala keluarga yang belum atau tidak memiliki pekerjaan. Hal ini memicu terjadinya disorientasi pembagian kerja di dalam keluarga warga terdampak. Tidak adanya pekerjaan yang dilakukan, membuat mereka hanya berdiam diri di rumah memanfaatkan harta yang masih tersisa pasca penggenangan.

Bagi sebagian warga lain, mereka melihat adanya peluang yang dapat digunakan untuk memaksimalkan kerja atau peran anggota keluaga mereka. Mereka mulai berjualan di sekitar waduk, terutama pada para ibu rumah tangga/perempuan Beberapa warga lelaki juga mulai menjadi penangkap ikan dan menggantungkan hidup pada perikanan. Di dalam aktivitas tangkap ikan, biasanya peran istri/perempuan tidak tampak kecuali dalam bidang penjualan hasil ikan tangkapan. Selain itu, pembagian jam kerja pasca penggenangan juga menjadi tidak teratur. Pengunjung yang datang ke waduk pada jam-jam tertentu seringkali membuat warga menunda waktu pulang ke rumah dengan harapan ada pengunjung yang datang waduk akan berbelanja di warung mereka atau menyewa perahu.

\section{Ekonomi Politik}

Hubungan sosial warga terdampak terbentuk dengan beberapa kelompok warga lain di tempat relokasi. Pada dasarnya, terdapat beberapa alasan mengapa masyarakat terdampak memilih tempat tinggal mereka yang baru. Salah satunya karena mereka memiliki kerabat terutama orang tua. Berpindahnya warga terdampak genangan ke Dusun Ancol salah satunya juga didasari oleh alas an ini. Selain itu, relasi sosial yang sudah terjalin dapat dimanfaatkan dalam kegiatan pindahan dan hal ini dapatmengurangi biaya beban angkut barang. Aneka kemudahan dalam menjalin relasi di tempat tinggal baru pun terjadi karena landasan relasi ini. Kebiasaan "gotong royong, saling asah, asih,asuh” dalam 
masyarakat Sunda, membuat warga memilih tinggal dengan para kerabatnya di saat sulit.

Alasan kepindahan warga ke dusun Ancol juga karenakemudahan terutama dalam bidang ekonomi. Warga yang pindah ke Dusun Ancol mayoritas tidak perlu membeli lahan lagi, karena mereka telah mendapatkan lahan dari orang tua ataupun kerabat yang telah memiliki lahan di dusun tujuan. Dusun Ancol yang merupakan daerah sekitar genangan, membuat biaya angkut jauh lebih murah dibandingkan dengan pindah ke daerah yang jauh dari tempat tinggal sebelumnya. Selain itu, memiliki kerabat di Dusun Ancol, diharapkan dapat memudahkan masyarakat terdampak untuk mendapatkan mata pencaharian baru dengan memanfaatkan relasi yang telah ada sebelumnya.

Dari semua faktor pendukung adaptasi, faktor modal dianggap paling berpengaruh, dan bukan faktor relasi sosial. Alasannya, relasi sosial yang ada tidak serta merta membuat mereka mudah mendapatkan pekerjaan. Namun, dengan adanya modal usaha, mereka akan mencari jalan untuk mulai bangkit beradaptasi dengan mata pencaharian baru. Ketika suatu populasi atau masyarakat mulai menyesuaikan diri terhadap suatu lingkungan yang baru, suatu proses perubahan akan dimulai dan dapat saja membutuhkan waktu yang lama untuk dapat menyesuaikan diri (Moran, 1982 dalam Arkan, 2015). Penyesuaian perubahan ini dapat berlangsung cepat atau lambat tergantung pada kemampuan mereka melihat kesempatan dan ketersediaan modal.

Di dalam upaya memanfaatkan relasi soal baik kepada warga yang berasal dari tempat tinggal sama atau berbeda, ataupun kepada warga lokal, menurut masyarakat terdampak Dusun Ancol sama saja. Tidak ada upayaupaya lebih. Hanya saja, hubungan dengan masyarakat terdampak dari daerah yang sama hanya pada komunikasi di awal kepindahan. Biasanya mereka akan berkomunikasi lebih intens dengan masyarakat terdampak yang berasal dari desa yang sama. Namun lambat laun mereka mulai membuka relasi dengan masyarakat terdampak dari wilayah yang berbeda.

Setelah penggenangan, jarang ditemukan kasus patron-klien seperti di tempat tinggal sebelumnya. Sehingga tidak ada masyarakat terdampak yang "ikut bekerja” dengan temannya atau dengan tuan tanahnya di daerah sebelum penggenangan. Namun mereka mengakui, tak jarang ada masyarakat terdampak yang lebih dahulu mendapatkan pekerjaan karena selain adanya modal, mereka telah memiliki relasi sosial dengan warga di desa yang baru sehingga mereka mengerti daerah setempat, atau dengan orang-orang yang memiliki orientasi mata pencaharian yang sama, termasuk mengenai sumber daya dan potensi mata pencaharian yang bisa dilakukan. Dapat dikatakan, relasi menjadi jalan pertama membuka cara untuk mendapatkan mata pencaharian.

\section{Analisis Adaptasi Mata Pencaharian}

Perubahan sumber daya lahan menjadi sumber daya air merupakan salah satu faktor terbesar dari dilakukannya adaptasi mata pencaharian oleh para informan. Perubahan sumber daya alam telah berpengaruh terhadap proses kehidupan masyarakat terdampak di tempat tinggal baru mereka. Berbicara tentang perubahan, terutama terkait mata pencaharian, adaptasi menjadi faktor penting.

Di dalam proses adaptasi dengan lingkungan baru, banyak hal yang harus mereka lakukan sehingga adaptasi dapat berhasil. Tak jarang, mereka harus memulai sesuatu yang baru yang sebelumnya belum pernah dicoba atau dilakukan. Setelah memilih daerah tempat tinggal baru, masyarakat terdampak menemui sesuatu yang baru dan berbeda dengan tempat tinggal sebelumnya, yakni sumber daya air waduk, untuk itu diperlukan adaptasi sosial dan /ekonomi dan adaptasi lingkungan untuk mengatasi kesulitan yang ada dilingkungan barunya.

Marvin Harris dalam teorinya mengenai materialism kebudayaan memberikan gambaran bahwa variabel infrastruktur kebudayaan seperti teknologi, ekosistem, dan 
pola kerja yang termasuk dalam mode of production merupakan hal yang dapat mendukung terjadinya adaptasi. Sedangkan demografi merupakan bagian dari mode of reproduction yang harus dikendalikan agar adaptasi dapat dilakukan dengan baik. Masyarakat harus menghindari peningkatan atau pengurangan jumlah dan ukuran penduduk yang bersifat mengganggu atau merusak (Saifuddin, 2005). Infrastruktur kebudayaan ini yang secara probabilitas dapat mempengaruhi kondisi struktur kebudayaan masyarakat yang termasuk di dalamnya pembagian kerja, dan hubungan dengan kelompoknya ataupun luar kelompoknya.

Sebelum penggenangan, warga terdampak sudah terbiasa dengan kehidupan pertanian, hal ini dikarenakan lebih dari 70\% Teknologi pertanian dimanfaatkan untuk mendukung mata pencahariannya. Bentang alam pertanian membuat warga memiliki strategi memaksimalkan cara kerja untuk mengolah lahan sawah mereka atau menyediakan jasa untuk menjadi buruh tani. Tak jarang, anggota keluarga seperti istri dan anak dilibatkan dalam proses kerja. Mereka biasanya akan membantu dari mulai proses pra panen atau penanaman, panen, dan pasca panen. Hal tersebut dilakukan guna meminimalisir biaya produksi, yakni memberi upah kepada buruh tani.

Pada beberapa warga yang menggunakan jasa buruh tani, mereka akan menggunakan jasa buruh tani yang sudah biasa ikut mengolah tanah mereka yang mereka anggap terpercaya. Setelah habis masa panen, hubungan antara pemilik lahan dan buruh tani tidak serta merta selesai. Banyak kasus bahwa pemilik lahan menjadi tempat buruh tani untuk berhutang, baik uang ataupun barang. Pemilik lahan biasanya memberikan pinjaman pada buruh tani yang memang sudah memiliki reputasi yang baik dari segi kinerja ataupun hubungan sosial. Sehingga hubungan mereka tidak sekedar pemilik lahan dan buruh saja.

Setelah penggenangan, terjadi perubahan kondisi bentang alam dari yang semula pertanian menjadi perairan (aquatiq). Perubahan ini menuntut masyarakat terdampak untuk melakukan adaptasi sesuai dengan sumber daya yang ada. Warga terdampak genangan harus berkompetisi untuk dapat memanfaatkan waduk sebagai sarana untuk mampu bertahan hidup. Air waduk yang saat ini berada disekitar mereka dimanfaatkan dalam bidang wisata atau ikan tangkapHal ini sesuai dengan batasan Soekanto yang melihat batasan adaptasi yakni proses mengatasi halangan-halangan dari lingkungan dan proses perubahanperubahan menyesuaikan dengan situasi yang berubah. (Soekanto,2005).

Perubahan bentuk mata pencaharian mereka berdampak pada jenis teknologi atau alat yang digunakan dalam bekerja. Warga terdampak genangan juga memanfaatkan relasi sosial mereka. Bagi masyarakat terdampak yang pindah ke Dusun Ancol dengan alasan memiliki kerabat atau orang tua akan lebih mudah beradaptasi, sebab mereka memanfaatkan relasi sosial tersebut untuk beradaptasi di lokasi yang baru. Bagi warga yang tidak punya kerabat, mereka pun membangun relasi sosial yang baru sebagai salah sati cara beradaptasi.

Namun, relasi sosial bukanlah hal utama yang dapat membantu adaptasi warga dalam penhidupan. Modal ginansial tetap menjadi landasan utama bagi terciptanya lapangan pekerjaan di tempat baru. Warga yang memiliki modal yang bisa bersumber dari sisa harta merekadan melihat peluang usaha baru lebih cepat menemukan sumber penghidpuan di tempat baru. Misal, dengan emmanfaatkan waduk sebagai sumber tangakapan ikan dan pariwisata.

Soekanto (2005), menyatakan bahwa batasan adaptasi ialah mereka dapat mengubah diri mereka agar sesuai dengan kondisi yang diciptakan. Selain itu, dapat dilihat bahwa orang yang mampu beradaptasi adalah mereka yang memanfaatkan sumber-sumber yang terbatas untuk kepentingan lingkungan dan sistem. Sebagian warga terdampak berhasil menciptakan aktivitas yang memberi keuntungan sesuai dengan keadaan bentang 
alam yang saat ini ada atau waduk. Mereka mengubah pola kerja, teknologi, dan sistem kerja yang merupakan upaya dalam penyesuaian budaya dan aspek lainnya sebagai hasil seleksi alamiah. masyarakat terdampak yang dapat menyesuaikan diri dengan aspek aspek yang dalam hal ini sesuai dengan batasan adaptasi ini yang mampu beradaptasi.

Tabel 2. Komposisi mata pencaharian penduduk sebelum dan setelah penggenangan

\begin{tabular}{|c|c|c|c|c|c|}
\hline \multirow[t]{2}{*}{ No } & \multirow[t]{2}{*}{$\begin{array}{c}\text { Mata } \\
\text { pencaharian }\end{array}$} & \multicolumn{2}{|c|}{$\begin{array}{c}\text { Sebelum } \\
\text { pengenangan }\end{array}$} & \multicolumn{2}{|c|}{$\begin{array}{c}\text { Setelah } \\
\text { penggenangan }\end{array}$} \\
\hline & & $\begin{array}{c}\text { Jumlah } \\
\text { KK }\end{array}$ & $\%$ & $\begin{array}{c}\text { Jumlah } \\
\text { KK }\end{array}$ & $\%$ \\
\hline 1 & Petani & 110 & 59,8 & 12 & 6,52 \\
\hline 2 & Kuli/buruh & 4 & 2,2 & 18 & 9,7 \\
\hline 3 & $\begin{array}{l}\text { Pegawai } \\
\text { Swasta }\end{array}$ & 8 & 4,34 & 9 & 4,89 \\
\hline 4 & PNS & 7 & 3,80 & 5 & 2,72 \\
\hline 5 & Wiraswasta & 1 & 0,54 & 1 & 0,54 \\
\hline 6 & Pensiunan & 12 & 6,52 & 12 & 6,52 \\
\hline 7 & Dagang & 7 & 3,80 & 22 & 11,96 \\
\hline 8 & Honorer & 5 & 2,71 & 5 & 2,71 \\
\hline 9 & Pemancingan & - & - & 1 & 0,54 \\
\hline 10 & Satpam & 1 & 0,54 & - & - \\
\hline 11 & Supir & 3 & 1,63 & 3 & 1,63 \\
\hline 12 & Ternak & - & - & 28 & 15,21 \\
\hline 13 & $\begin{array}{l}\text { Pengemudi } \\
\text { Perahu }\end{array}$ & - & - & 3 & 1,63 \\
\hline 14 & Waring Ikan & - & - & 1 & 0,54 \\
\hline 15 & Jaring Ikan & - & - & 3 & 1,63 \\
\hline 16 & $\begin{array}{l}\text { Tidak } \\
\text { Bekerja }\end{array}$ & 5 & 2,71 & 40 & 21,74 \\
\hline 17 & $\begin{array}{l}\text { Tidak ada } \\
\text { Data }\end{array}$ & 21 & 11,41 & 21 & 11,41 \\
\hline Jum & h KK & 184 & 100 & 184 & 100 \\
\hline
\end{tabular}

Sumber: Data primer, 2016

Pasca penggenangan, pertanian yang menjadi sumber penghidupan warga pun hilang. Dari data awal sebanyak 110 KK (59,8\%) yang menjadi petani, setelah penggenangan hanya 12 (6,52\%) orang saja yang masih menjadi petani. Setelah penggenangan, warga menggarap lahan yang di lokasi tidak tergenang. Jumlah petani penggrapa menurun drsatis karena tidak adal lagi lahan yang digarap. Namun, jumlah pedagang justru mengalami kenaikan. Selain itu, bentuk mata pencaharian lain pun muncul yakni penyewaan perahu, jaring ikan, dan waring ikan. Perubahan ini membuat orientasi ekonomi warga terdampak berubah. Sebelum penggenangan biasanya masyarakat terdampak baru akan mendapatkan hasil kerjanya setelah panen tiba. Selain itu, mereka akan menjadikan hewan ternak sebagai harta simpanan yang akan digunakan bila ada keperluan mendesak.

Setelah penggenangan, mereka tidak lagi mendapatkan hasil per 6 bulan sekali seperti setiap waktu panen, melainkan bisa setiap hari. Sebab, mereka akan bergantung pada banyaknya jumlah pengunjung yang datang ke waduk sekitar tempat tinggal mereka. Sehingga, pola kerja yang mereka terapkan akan berubah.

Pada saat menjadi petani, mereka akan bekerja dengan jadwal yang tepat yakni dari paling pagi pukul 6 dan paling siang pukul 12 di sawah. Namun, setelah penggenangan jadwal mereka disesuaikan menurut pekerjaannya sekarang. Penjaring ikan dan pengemudi perahu akan berangkat pukul 5 pagi untuk mengecek jaringnya dan untuk berjaga bila ada pemancing yang akan berangkat ke desa seberang. Mereka akan kembali ke rumah pukul 5 sore atau lebih malam lagi. Pedagang akan mulai aktivitas pada pukul 7 pagi dan pulang pukul 5 sore. Namun setelah penggenangan, warga jarang sekali yang masih memanfaatkan ternak untuk menjadi harta simpanan, sebab ternak mereka sudah habis untuk membangun rumah di tempat baru. Sumber: Data primer, 2016

Merujuk pada konsep infrastruktur pada teori materialisme kebudayaan Marvin Harris, tatanan struktur warga terdampak telah berubah. Meraka harus merubah pembagian kerja di dalam rumah tangga. Banyak istri yang tidak lagi bekerja atau menjadi bekerja pasca penggenangan. Warga yang pindah ke tempat baru juga kembali membangun relasi sosial dalam rangka adaptasi di lingkungan sosial baru Di tempat baru, umumnya mereka memanfaatkan relasi intergrup untuk mendapatkan informasi tentang mata pencaharian.

Mata pencaharian baru yang berbasis perairan membutuhkan keahlian khusus, seperti menjaring ikan dan mengemudikan perahu. Mengingat keahlian sebagian besar warga adalah di bidang pertanian, tak banyak warga yang beralih pada penghidupan 
berbasis air ini. Hanya ada sekitar 8 dari ratusan kepala keluarga yang memilih jenis penghidupan baru ini. Kedelapan warga ini berharap bahwa hasil atau pendapatan yang lebih dengan memanfaatkan potensi dari adanya waduk dapat mereka jadikan sandaran hidup.

Perubahan mata pencaharian yang dilakukan masyarakat terdampak merupakan pilihan rasional atas perkiraan yang diharapkan akan dapat memperbaiki kehidupan perekonomian mereka. Warga yang tidak atau belum memiliki mata pencaharian hingga saat ini biasanyadikarenakan tidak adanya upaya lebih untuk berusaha atau kurangnya akses modal finansial sebagai penunjang mendapatkan mata pencaharian baru.

\section{Simpulan}

Dari hasil penelitian ini dapat disimpulkan bahwa keberadaan Waduk Jatigede merubah variabel infrastruktur yang juga mengubah variabel struktur, dan suprastruktur kebudayaan. Hal ini dapat dianalisis dengan kacamata teori materialisme kebudayaan yang dikemukakan oleh Marvin Harris. Variabel-variabel yang dikaji pada penelitian ini menggambarkan perubahan pada warga terdampak Dusun Ancol berproses dalam upaya beradaptasi dengan Lingkungan hidup yang baru.

Pembangunan Waduk Jatigede dalam hal ini telah mengakibatkan perubahan lahan sawah menjadi perairan, berkurangnya lahan sawah, dan perubahan kondisi jalan. Selain itu, perubahan ini juga membuat berubahnya teknologi yang digunakan untuk mendukung mata pencaharian mereka. Proses-proses perubahanini kemudian mengakibatkan perubahan struktur kebudayaan seperti bidang sosial/ekonomi, berupa berubahnya pembagian kerja anggota keluarga dan berubahnya kondisi relasi intergrup atau intragrup. Perubahan ini secara langsung maupun tidak langsung telah membuat proses adaptasi pada masyarakat terdampak termasuk pada adaptasi mata pencaharian.
Sebelum penggenangan sebagian besar mata pencaharian masyarakat terdampak ialah petani. Pembangunan Waduk Jatigede menyebabkan mereka kehilangan mata pencaharian lama. Di tempat tinggal baru masih sedikit sekali warga yang masih mendapatkan akses sumber daya lahan karena lahannya telah dimiliki warga setempat, sehingga mereka harus mencari sumber daya lain untuk dimanfaatkan. Sumber daya air yang dapat membuka peluang usaha baru dan dapat dipilih warga terdampak untuk mendapatkan mata pencaharian belum menarik minat warga. Hal itu bsia jadi disebabkan oleh belum adanya pelatihan ketrampilan untuk penghidupan di bidang perairan. Pendapatan yang menurun membuat kesejahteraan rumah tangga warga menurun. Dengan demikian, tujuan pembangunan untuk meningkatkan taraf kesejahteraan belum dapat tercapai atau dengan kata lain pembangunan ini belum berhasil untuk mencapai tujuannya.

Dari hasil penelitian ini dapat disimpulkan bahwa pembangunan yang membuat perubahan infrastruktur kebudayaan turut mengubah struktur kebudayaan. Perubahan ini diakibatkan oleh variabel dalam mode of production dan mode of reproduction pada tahap infrastruktur berubah, sehingga variabel dalam political economy dan domestic economy yang termasuk bagian dalam struktur menjadi berubah. Hal ini sejalan dengan konsep determinisme kebudayaan yang dikemukakan oleh Marvin Harris.

\section{Ucapan terima kasih}

Penelitian ini didanai oleh Universitas Padjadjaran melalui Skema Penelitian Academic Leadership Grant (ALG) tahun anggaran 20152016 dengan judul Resettlement Terdampak Pembangunan Waduk Jatigede. Tim penulis mengucapkan terima kasih pada Rektor, Dekan, dan DRPM Universitas Padjadjaran para informan penelitian, serta semua pihak yang atas support yang telah diberikan bagi terlaksananya penelitian dan publikasi ini. 


\section{Daftar Pustaka}

Arkan, H. I. (2015). Strategi Adaptasi Masyarakat Terkait Bencana Kekeringan. Proposal Penelitian. Tidak diterbitkan.

Bungin, B. (2007). Penelitian Kualitatif. Jakarta: Prenada Media Group.

Effendi, B. (2002). Pembangunan Daerah Otonomi Berkeadilan. Yogyakarta: Uhaindo dan Offset.

Fahim, H. M. (1981). Dams, People and Development (The Aswan High Dam Case). New York: Pergamon Press Inc.

Gerungan, W. A. (2009). Psikologi sosial. Bandung: PT Refika Aditama.

Harahap, S. A. (2015). Dampak Pembangunan Hotel Sutan Raja dan Sekolah Yadika Terhadap Mata Pencaharian Petani di Desa Cingcin. Bandung: Universitas Padjadjaran.

Harris, M. (1979). Cultural Materialism. United States: Library of Congress Cataloging in Publication Data.

Irwan, Z. D. (2014). Prinsip-Prinsip Ekologi. Jakarta: Bumi Aksara.

McMillan, J. H., \& Schumacher, S. (2001). Research in education: A conceptual introduction (5th ed.). New York: Longman.

PPSDAL, (1999/2000). Pemantauan Keadaan Sosial Ekonomi Penduduk Asal Jatigede Yang Telah Pindah Ke Lokasi Pemukiman Baru. Bandung : Universitas Padjadjaran.

Rosni. (2012). Analisis Tingkat Kesejahteraan Nelayan di Desa Dahari Selebar Kecamatan Talawi Kabupaten Batubara.

Saifuddin, A. F. (2005). Antropologi Kontemporer (Suatu Pengantar Kritis Mengenai Paradigma). Jakarta: Kencana.

Soekanto, S. (2000). Sosiologi Suatu Pengantar. Jakarta: PT Raja Grafindo Persada.

Symon, G. dan Cassell, C. (1998) Qualitative Methods and Analysis in Organisational Research. London: Sage Publication

Soemarwoto, O. (2003). Analisis Mengenai Dampak Lingkungan. Yogyakarta: Gadjah Mada University Press.

Soemarwoto, O. (2004). Ekologi, Lingkungan Hidup dan Pembangunan. Jakarta: Djambatan.

Suwartapradja, O. S. (2008). Disertasi. Strategi Penduduk Daerah Rencana Genangan Dalam Menghadapi Ketidakpastian
Pembangunan Waduk Jatigede Di

Kabupaten Sumedang, Jawa Barat.

Bandung: Program Pasca Sarjana

Sosiologi Konsentrasi Antropologi FISIP

Universitas Padjadjaran.Tidak

diterbitkan.

Suwartapradja, O. S. (2015). Laporan Penelitian. Kondisi Sosial Terdampak Pembangunan Waduk Jatigede. Skema BPON DIKTIFISIP Universitas Padjadjaran- Tidak diterbitkan.

Suwartapradja, OS.(2016). Laporan Penelitian. Resettlement Terdampak Pembangunan Waduk Jatigede. Bandung, Skema Academic Leadership Grant (ALG). Departemen Antropologi Fisip-DRPM Universitas Padjadjaran. Tidak diterbitkan. 